\title{
Signalling the Enforceability of the Forum's Judgments Abroad
}

\author{
Gilles Cuniberti*
}

The aim of this Article is to document and assess the efforts made by international commercial courts to signal the enforceability of their judgments abroad. To that effect, three strategies were developed. The first and most obvious one was to enter into agreements providing for the mutual enforcement of judgments of contracting states which could serve the same function as the $1958 \mathrm{New}$ York Convention for arbitral awards. Yet, as the 2005 Hague Convention has a limited scope and the 2019 Hague Convention is not yet in force, alternative strategies were identified. Several international commercial courts are actively pursuing the conclusion of non binding documents with other courts or even law firms suggesting that the judgments of the forum would be enforced by the courts of other states. Finally, one international court has also explored how it could convert its judgments into arbitral awards.

\section{Contents}

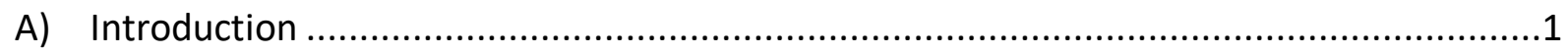

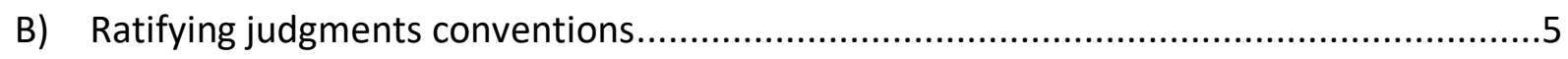

C) Signing non binding memoranda suggesting enforceability ......................................

1) Memoranda of Guidance signed with foreign courts............................................

2) Guiding Notes issued by foreign law firms.....................................................10

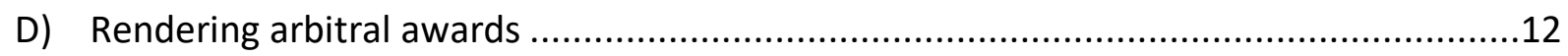

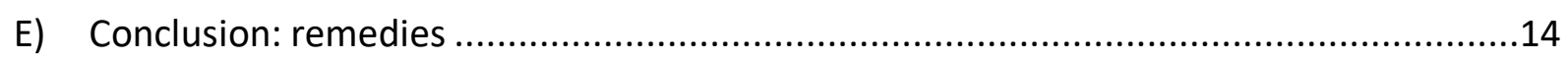

\section{A) Introduction}

Private international law has traditionally been concerned with the recognition and enforcement of foreign judgments in the forum. In contrast, private international law does not address the recognition and enforcement of the judgments rendered by the courts of the forum in other jurisdictions. This is because, under public international law, states lack jurisdiction to regulate the enforcement of their own judgements on the territory of other states. Enforcement may lead to the use of force to compel the judgment debtor to satisfy the judgment, and use of force falls within the exclusive jurisdiction of the state on the territory of which such force may be used. Likewise, recognition of foreign judgments may impact proceedings in the forum, for instance by triggering res judicata. Again, states have exclusive jurisdiction to organize the functioning of their organs, including their judicial organs. In principle, civil procedure must be governed

\footnotetext{
* Professor of Private International Law, University of Luxembourg. Email: gilles.cuniberti@uni.lu Many thanks to Karim El Chazli and Geneviève Saumier for useful comments. All errors are mine.
} 
by the law of the forum, and it is thus for the law of the forum only to determine whether a foreign judgment might be res judicata and prevent relitigation in the forum.

States caring for the fate of their judgments in other jurisdictions are thus essentially left with two options. The first is to unilaterally pressure foreign governments and/or courts to enforce forum's judgments. This is one rationale for adopting a reciprocity requirement, ${ }^{1}$ though clearly not the only one. ${ }^{2}$ The second option is to enter into treaties with other states providing for mutual enforcement of judgments. Certain states have actively pursued a policy of negotiating bilateral treaties to that effect and concluded dozens. ${ }^{3}$ Yet, as certain states have never entered into any such bilateral treaty, ${ }^{4}$ the policy has obvious limitations which could only be overcome by a multilateral instrument. But, until recently, it did not seem that there was much prospect for the establishment of a broad multilateral scheme. A Convention on the Recognition and Enforcement of Foreign Judgments in Civil and Commercial Matters was adopted under the aegis of the Hague Conference for Private International Law in February $1^{\text {st }}$, 1971, and entered into force in 1979, but it was ratified by only five states, four of which European. ${ }^{5}$

It is remarkable that, while bilateral treaties were entered into as early as in the $19^{\text {th }}$ century ${ }^{6}$ and the New York Convention on the Recognition and Enforcement of Foreign Arbitral Awards ${ }^{7}$ was adopted in 1958, the Hague Judgments Convention was only adopted in $2019,{ }^{8}$ and the Hague Choice of Court Convention in 2005. ${ }^{9}$ There are likely many reasons why negotiating multilateral conventions on foreign judgments is extremely difficult. As is well known, ${ }^{10}$ the negotiations under the aegis of the Hague Conference failed once, led to the adoption of a less ambitious instrument (the 2005 Hague Convention), were then resumed to eventually lead to the adoption of the 2019 Hague Convention. Yet, until recently, it might be that the most important reason was simply that ensuring the enforceability of local judgments abroad was a low priority for most states which simply did not care much, if at all, about the fate of their judgments in other states. ${ }^{11}$

\footnotetext{
${ }^{1}$ See D Martiny, "Recognition and Enforcement of Foreign Money Judgments in the Federal Republic of Germany”, (1987) Am. J. Comp. L. 721, 749 ; H Linke \& W Hau, Internationales Zivilverfahrensrecht (Ottoschmidt, $6^{\text {th }}$ ed 2015) para 13-46 ; J Coyle, "Rethinking Judgments Reciprocity", (2014) North Carolina LR 1109.

${ }^{2}$ Many states have adopted a reciprocity requirement to ensure that their sovereignty would be fully respected by other states: see P Lagarde, "La réciprocité en droit international privé" (1977) 154 Collected Courses of the Hague Academy of International Law 111 ; B Elbalti, "Reciprocity and the recognition and enforcement of foreign judgments: a lot of bark but not much bite", (2017) J. Priv. Int. L. 184 ; G Cuniberti, "Le fondement de l'effet des jugements étrangers" (2018) 394 Collected Courses of the Hague Academy of International Law 101, 201.

${ }^{3}$ Examples include the People's Republic of China and France.

${ }^{4}$ This is the case, for instance, of the United States.

${ }^{5}$ The contracting states are Albania, Cyprus, Kuwait, the Netherlands, and Portugal.

${ }^{6}$ France and Switzerland entered into a bilateral treaty in 1869 , for instance (it was terminated in 1992).

${ }^{7}$ Hereafter 'the New York Convention'.

${ }^{8}$ Convention of 2 July 2019 on the Recognition and Enforcement of Foreign Judgments in Civil or Commercial Matters (hereafter '2019 Hague Convention').

${ }^{9}$ Convention of 30 June 2005 on Choice of Court Agreements (hereafter '2005 Hague Convention')

${ }^{10}$ See, e.g., A Bonomi, "Courage or Caution? A Critical Overview of the Hague Preliminary Draft on Judgments" (2015-2016) Yearbook Private Int L 1; P Beaumont, "The revived Judgments Project in The Hague", (2014) Nederlands Internationaal Privaatrecht 532 ; R Brand, "Jurisdictional Developments and the New Hague Judgments Project", in A Commitment to Private International Law: Essays in Honour of Hans van Loon (Intersentia, 2013) 89.

${ }^{11}$ The limited success of the 1971 Hague Convention certainly supports this conclusion. It is true that it included a burdensome requirement of additional bilateral agreements between the contracting states (see Art 21), but this reveals that the interest of states was not strong enough to abandon control over the enforcement of foreign judgments.
} 
One possible explanation is that adjudication has traditionally been perceived as an attribute of state sovereignty. The judicial power is one of the three branches of government. Its constitutional function is to apply and interpret laws passed by the legislative branch and exercise a check on the two political branches. In many legal systems, the judiciary decides cases in the name of the people constituting the local polity. The role of courts, therefore, was to exercise their constitutional functions, and to deliver justice to the people residing locally. Despite the contribution of private international law to the coordination of legal systems ${ }^{12}$ and the long recognised power to apply foreign law, the representation of judicial power led it to look primarily inward. ${ }^{13}$

In recent years, however, a shift in paradigm has occurred. In many parts of the world, adjudication began to be perceived as a business. A number of states established new courts, or new divisions in their courts, for the purpose of attracting judicial business. The rise of international commercial courts has been largely documented in recent years, ${ }^{14}$ and it is barely necessary to remind readers of this journal of the establishment of new commercial courts in Asia, the Middle East and Continental Europe. While these courts have different aims and goals, they all have in common the need to market themselves to potential users. And many have concluded that the enforceability of their judgments abroad is an essential dimension of their marketability. As this Article will document, many international commercial courts have been making important efforts towards signalling the enforceability of their judgments abroad, showing that, in the new paradigm, the issue can become very high priority.

Obviously, unenforceable judgments are not useful for judgments creditors, and indeed for the legitimacy of the rendering court. One should not forget, however, that, contrary to arbitral awards, judgments are typically enforceable in the forum, and might not need, therefore, to be enforced abroad. This is an important advantage for courts established in major financial centres such as London, where many debtors may hold assets. It should also be underlined that, while the ultimate goal of newly established international commercial courts might be to attract disputes with no connection with the forum, the truth of the matter is that some of these courts will not attract many of these cases, and will essentially adjudicate disputes involving a local party. ${ }^{15}$ Where this will be the case, and where this local party will be the judgment debtor, it will typically be possible to enforce the judgment within the jurisdiction of the rendering court. The issue of enforceability of judgments abroad will be essential for courts aiming at being chosen as neutral fora for the resolution of disputes involving foreign parties only.

Neutrality of adjudication has been the single most important advantage of arbitration over litigation and probably the main reason for the success of international commercial arbitration

\footnotetext{
${ }^{12}$ Certain doctrines of private international law such as forum non conveniens can take into account the enforceability of judgments abroad.

${ }^{13}$ In its most extreme form, courts in certain jurisdictions have even designed rules limiting access for nonresidents, as the latter did not fund the local court system through their taxes: this is the case of U.S. courts, who give deference to U.S. plaintiffs over foreign plaintiffs: see Iragorri v. United Technologies Corp. 274 F.3d 65 (2d Cir. 2001).

${ }^{14}$ See, e.g., X Kramer \& J Sorabji (eds) International Business Courts: A European and Global Perspective (Eleven International Publishing 2019); M Requejo, "International Commercial Courts in the Litigation Market" (2019) Int'l J. Procedural L. 4; M. Erie, “The New Legal Hubs: The Emergent Landscape of International Commercial Dispute Resolution" (2019) 59 Virginia J Int L. _; P Bookman, "The Adjudication Business" (2020) Yale J. Int. L. . See also the articles focusing on certain specific courts cited infra n $24 \& 86$.

15 The first cases handled by the Paris international chambers correspond to this model, for instance: see https://www.cours-appel.justice.fr/paris/arrets-des-chambres-commerciales-internationales-de-paris-0 accessed 12 Nov. 19.
} 
in the last decades. ${ }^{16}$ It will therefore be an obvious competitor for international commercial courts aiming at attracting international disputes unconnected to the forum. But arbitration has a fundamental advantage over international commercial courts, which no doubt also explains why the issue of enforceability of judgments abroad has become so acute: the 1958 New York Convention. The New York Convention has largely harmonised the laws of arbitration of most states in the world with respect to enforcement of foreign awards. To date, it has been ratified by 160 states, which makes it an almost universal instrument. The New York Convention sets a limited number of grounds for reviewing arbitral awards ${ }^{17}$ and thus forbids contracting states from denying recognition or enforcement of foreign arbitral awards on any other ground. ${ }^{18}$ As there is no equivalent instrument regulating the enforcement of judgments at world level, the New York Convention grants arbitral awards a unique international currency. Arbitral awards can be enforced under the Convention worldwide. The enforceability of awards has typically been presented as a key advantage of arbitration as a mode of resolution of international commercial disputes. ${ }^{19}$

If one has a closer look to the New York Convention regime, however, it immediately appears that the Convention does not guarantee enforcement of arbitral awards. Art V provides for a certain number of grounds for denying enforcement, and one in particular, the public policy exception, is sufficiently vague to grant significant discretion to enforcing courts in this respect. Arbitration specialists know all too well that a number of contracting states have interpreted the public policy exception broadly. ${ }^{20}$ Additionally, it must be underscored that the New York Convention is an international text which is interpreted by the courts of all contracting states. No court has authority to issue binding interpretations of the Convention. As a result, it is only logical that the courts of the different contracting states interpret differently the provisions of the Convention. It follows that the New York Convention does not genuinely establish a uniform regime for the enforcement of foreign arbitral awards. It only harmonises the field to a large extent.

Despite these qualifications, it remains that the existence and the success of the New York Convention affords an easy and simple argument to supporters of arbitration. The argument could be made with various degrees of sophistication and correctness. In its most sophisticated form, it should be made with the qualification that the law of the place where enforcement of the award is likely should be verified. One would think that lawyers discussing with their client the desirability to include an arbitration clause in their contract would at least raise this point. But the argument could be made in a much simpler and bolder form: arbitral awards are generally enforceable throughout the world, and enforcement is therefore unlikely to be an

\footnotetext{
${ }^{16}$ See e.g. J. Paulsson, "International Arbitration is not Arbitration" (2008) Stockholm. Int. Arb. R. 1; N Blackaby, C Partasides, A Redfern \& M Hunter, Redfern \& Hunter on International Commercial Arbitration (OUP $6^{\text {th }}$ ed. 2015), para 1.99.

${ }^{17}$ New York Convention, Art. V.

${ }^{18}$ The New York Convention, however, allows contracting states to be more favorable to arbitration and to enforce foreign arbitral awards where a ground of review provided by the Convention exists: see Art VII.

${ }^{19}$ See, e.g., N Blackaby, C Partasides, A Redfern \& M Hunter, n 16, para 1.102.

${ }^{20}$ Examples include Russia (see B Karabelnikov \& D Pellew, "Enforcement of International Arbitral Awards in Russia - Still a Mixed Picture" (2008) 19 ICC Bulletin 65), Poland (see J Koepp \& A Ason, “An AntiEnforcement Bias? The Application of the Substantive Public Policy Exception in Polish Annulment Proceedings"” (2018) 35 J. Int. Arb. 157) and the People's Republic of China (M Qu, "Status Quo of Enforcing Commercial Arbitral Awards in the People's Republic of China: An Empirical Study of the Enforcement Practices in China's Two Economically Less-Developed Regions" (2019) 36 J. Int. Arb. 451).
} 
issue. One trusts that only persons confident that their liability could not be possibly triggered would make such arguments. They include a number of arbitration centres. ${ }^{21}$

The aim of this Article is to document and assess the efforts made by a number of international commercial courts to signal the enforceability of their judgments abroad to the market. To that effect, three strategies were developed. The first and most obvious was to enter into agreements providing for the mutual enforcement of judgments of contracting states (Part B). Yet, as the 2005 Hague Convention has a limited scope and the 2019 Hague Convention is not yet in force, alternative strategies were identified. Several international commercial courts are actively pursuing the conclusion of non binding documents of various kinds suggesting or asserting that the judgments of the forum would be enforced by the courts of other states (Part C). One international court has also explored how it could convert its judgments into arbitral awards (Part E). These strategies are presented and assessed in turn.

\section{B) Ratifying judgments conventions}

For states supporting the development of an international commercial court, the obvious alternative to the New York Convention is the 2005 Hague Convention. The 2005 Hague Convention provides for the recognition and enforcement of judgments in civil and commercial matters and allows contracting states to refuse to do so on a limited number of grounds only. ${ }^{22}$ It promises, therefore, to offer the same enforceability for judgments rendered in commercial cases that the New York Convention offers for arbitral awards.

The potential for signalling the enforceability of local judgments appeared to Singapore when it decided to establish its international commercial court on the model of the English commercial court. Although history will probably remember that Singapore signed and ratified the 2005 Hague Convention at an early stage, it was not among the first states which signed the Convention shortly after its adoption. The interest of Singapore in the Convention arose when the decision was made to establish the Singapore International Commercial Court ${ }^{23}$ and more generally to promote further Singapore as an international dispute resolution hub. ${ }^{24}$ The United Kingdom is another state which has felt a sudden urge to ratify the Convention. The UK ratified the Convention independently on December $28^{\text {th }}, 2018$. The Convention already applied in the UK at this date, as a consequence of the ratification of the European Union. The purpose of the independent ratification of the UK is to ensure that the Convention will apply on the day of Brexit, allowing the UK to continue to benefit from an international regime of mutual enforcement of judgements.

There are, however, many reasons why, at the present time, ratification of the 2005 Hague Convention is much less a guarantee of enforcement of local judgements abroad than the New York Convention is for arbitral awards. The first and most obvious one is that the 2005 Hague Convention is still at the stage of infancy. Although the ratification by the European Union

\footnotetext{
${ }^{21}$ See, for instance, this statement of the Singapore International Arbitration Center under the heading "What Singapore has to offer": 'A party to the 1958 New York Convention (on enforcement of arbitration awards). Singapore arbitration awards are enforceable in over 150 countries worldwide' (http://www.siac.org.sg/2014-1103-13-33-43/why-siac/arbitration-in-singapore accessed on 12 Nov 19), and the statement of the Arbitration Institute of the Stockholm Chamber of Commerce: 'An arbitral award is enforceable in more than 150 countries (New York Convention, 1958)' (https://sccinstitute.com/our-services/arbitration/ accessed on 12 Nov 19). 222005 Hague Convention, Art 8.

${ }^{23}$ It was in 2015 that Singapore both launched the court (Jan. $5^{\text {th }}$ ) and signed the Convention (March $25^{\text {th }}$ ).

${ }^{24}$ A Chong \& M Yip, "Singapore as a centre for international commercial litigation: party autonomy to the fore" (2019) 15 J. Priv. Int. L. 97, 119. In 2013, the Singapore Law Reform Committee had recommended to wait and see as the Convention would not bring practical benefits: see idem.
} 
immediately brought in 27 states, ${ }^{25}$ very few other states have ratified it. Thus, the 2005 Hague Convention does not offer any guarantee of enforcement in most states of the world, and likely will not for many years. There is nothing surprising or dishonourable about it. It took twenty years for the New York Convention to attract more than 50 (individual $^{26}$ ) contracting states. ${ }^{27}$ Yet, it means that, in the meantime, the 2005 Hague Convention will only have the potential of ensuring enforceability of foreign judgments in most states of the world, ${ }^{28}$ and will be a mere marketing argument for states supporting their international commercial courts.

Additionally, it must be underlined that the scope of the 2005 Hague Convention is subject to severe limitations. First, it only applies to exclusive jurisdiction clauses. ${ }^{29}$ As a result, it does not apply to cases where the parties provided for non exclusive jurisdiction clauses, which are common in certain industries, in particular international finance. Art 22 of the 2005 Hague Convention affords the possibility for certain contracting states to extend the scope of the instrument to non exclusive choice of court agreements in their mutual relationships by way of declarations, but remarkably neither Singapore nor the United Kingdom have made such declaration. It will thus be necessary to supplement the 2005 Hague Convention by the 2019 Hague Judgments Convention, which provides for the enforcement and recognition of judgments rendered on the basis of such clauses, ${ }^{30}$ but has yet to enter into force. Likewise, and contrary to arbitral tribunals, courts in general, and most international commercial courts, may be petitioned in absence of any agreement on jurisdiction. ${ }^{31}$ Indeed, a number of international commercial courts have been essentially petitioned in cases where the parties had not provided for the competent adjudicator. ${ }^{32}$ Again, the 2005 Hague Convention does not apply, and it will be necessary to supplement it by the 2019 Hague Convention. Second, the material scope of both the 2005 Hague Convention and the 2019 Hague Convention is limited. The two conventions do not apply, for instance, to insolvency and analogous matters, ${ }^{33}$ carriage of passengers or goods, ${ }^{34}$ most competition disputes ${ }^{35}$ and most intellectual property disputes. ${ }^{36}$ Where international commercial courts will decide disputes in these fields, none of the Hague Conventions will ensure enforceability of the resulting judgments.

\footnotetext{
${ }^{25}$ For institutional reasons, the EU did not represent Denmark, which ratified independently the Convention anyway.

${ }^{26}$ The member states of the EU, which were fewer at the time, could and did join individually.

${ }^{27}$ I counted that 55 states ratified or had otherwise become parties to the Convention by 1980 .

${ }^{28}$ Arguably, the ratification of the EU makes the situation different for any country supporting an international commercial court targeting more specifically disputes involving parties based in the EU. This is probably the most realistic prospect of newly established courts in continental Europe, but the enforceability of their judgments in other member states is already guaranteed by applicable EU Regulations. The benefits of the 2005 Hague Convention are much clearer for European states which are neither member states of the EU, nor contracting states to the Lugano Convention. This might be the case of the United Kingdom after Brexit. Yet, the market that the English commercial court targets is much wider than the EU, and for disputes involving parties based in third states, the 2005 Hague Convention does not guarantee enforcement of English judgments at the present time.

292005 Hague Convention, Art 1(1).

302019 Hague Convention, Art 5(1)(m).

${ }^{31}$ It is conceivable, of course, to design an international commercial court, the jurisdiction of which could only lie in the agreement of the parties. This was the case of the Brussels International Business Court in the bill which was proposed to, but ultimately rejected, by the Belgian parliament.

${ }^{32}$ This is the case of the international chamber of the Paris Commercial Court, for instance: see the judgments published at https://www.cours-appel.justice.fr/paris/arrets-des-chambres-commerciales-internationales-deparis-0 accessed on 12 Nov 19.

332005 Hague Convention, Art 2(2)(e) ; 2019 Hague Convention, Art 2(1)(e).

${ }^{34} 2005$ Hague Convention, Art 2(2)(f) ; 2019 Hague Convention, Art 2(1)(f).

${ }^{35} 2005$ Hague Convention, Art 2(2)(h) ; 2019 Hague Convention, Art 2(1)(p).

${ }^{36} 2005$ Hague Convention, Art 2(2)(n) ; 2019 Hague Convention, Art 2(1)(m).
} 
From a legal point of view, the argument that ratifying the 2005 Hague Convention ensures enforceability of local judgments abroad is premature and oversimplifying. ${ }^{37}$ But the truth of the matter is that the argument is not really legal, but commercial. It aims at marketing the judicial services of states which want to compete on the market of international commercial adjudication.

\section{C) Signing non binding memoranda suggesting enforceability}

An alternative strategy to signal the enforceability of judgments abroad is to foster the issuance of documents of various kinds suggesting or asserting that the judgments of the forum would be enforced by the courts of a given foreign state. As such documents are not binding on the courts of the foreign state, they cannot offer any benefit unless some weight can be attributed to the suggestions or assertions made. Bilateral Memoranda of Guidance signed with the courts of a given foreign state carry the weight of the residual authority that courts instil in any document they endorse (1). Opinions issued by law firms carry weight proportional to the financial risk taken by the opinion giver (2).

\section{1) Memoranda of Guidance signed with foreign courts}

A number of international commercial courts have signed non-binding memoranda of guidance with the courts of other countries to signal the enforceability of their judgments abroad. It seems that this innovative practice was initiated by the Dubai International Financial Centre Courts (hereafter 'DIFC Courts'). The DIFC Courts have entered into a bilateral 'Memorandum of Guidance' with courts of nine states: the Commercial Court of England and Wales, ${ }^{38}$ the Federal Court of Australia, ${ }^{39}$ the High Court of Kenya ${ }^{40}$ the Supreme Court of Singapore, ${ }^{41}$ the U.S. District Court for the Southern District of New York, ${ }^{42}$ the National administration of the Supreme Court of Korea, ${ }^{43}$ the Supreme Court of Kazakhstan, ${ }^{44}$ the Federal Court of Malaysia, ${ }^{45}$ and the High Court for Zambia. ${ }^{46}$ In addition, a memorandum is currently being negotiated with the High Court of Hong Kong, ${ }^{47}$ and a less ambitious 'Memorandum of

\footnotetext{
${ }^{37}$ In a report of November 2013, the Singapore International Court Committee even made the baffling argument that a "premise for the establishment of a new international court" was that "the New York Convention, while wide in its reach, may not be fully effective for enforcement in some countries." (Report of the Singapore International Court Committee, para 16, available at https://www.sicc.gov.sg/docs/default-source/modulesdocument/news-and-article/-report-of-the-singapore-international-commercial-court-committee- 90a41701a5fc-4a2e-82db-cc33db8b6603-1.pdf accessed on 12 Nov 19)

${ }^{38}$ Memorandum of Guidance as to Enforcement between the DIFC Courts and the Commercial Court, Queen's Bench Division, England and Wales, dated January 23 ${ }^{\text {rd }}, 2013$.

${ }^{39}$ Memorandum of Guidance Between The Federal Court of Australia and DIFC Courts, dated March $28^{\text {th }}, 2014$.

${ }^{40}$ Memorandum of Guidance between the Dubai International Financial Centre Courts and The High Court of Kenya, Commercial \& Admiralty Division, dated November 2014.

${ }^{41}$ Memorandum of Guidance as to Enforcement between the Supreme Court of Singapore and the Dubai International Financial Centre Courts, dated January 19 ${ }^{\text {th }}, 2015$.

${ }^{42}$ Memorandum of Guidance between Dubai International Financial Centre Courts and United States District Court for the Southern District of New York, Date March 22 $2^{\text {nd }}, 2015$.

${ }^{43}$ Memorandum of Guidance as to Enforcement between the Dubai International Financial Centre Courts and National Administration of the Supreme Court of Korea, dated November $4^{\text {th }}, 2015$.

${ }^{44}$ Memorandum of Guidance as to Enforcement between Supreme Court of the Republic of Kazakhstan \& DIFC Courts, dated 2015.

${ }^{45}$ Memorandum of Guidance between the Federal Court of Malaysia and the Dubai International Financial Centre Courts on Understanding the Enforcement of Foreign Money Judgments, dated 2016.

${ }^{46}$ Memorandum of Guidance between the Dubai International Financial Centre Courts and High Court for Zambia, dated 2017.

${ }^{47}$ Draft Memorandum of Guidance as to enforcement between the Dubai International Financial Centre Courts and the High Court of the Hong Kong SAR of the PRC, dated July $23^{\text {rd }}, 2018$.
} 
Understanding' was entered into with the Shanghai High People's Court. ${ }^{48}$ Singapore courts have also entered into similar memoranda of guidance with the DIFC courts (see above), the Abu Dhabi Global Market Courts, ${ }^{49}$ the Supreme Court of Victoria (Australia), ${ }^{50}$ the Supreme Court of Bermuda, ${ }^{51}$ the Qatar International Court and Dispute Resolution Centre ${ }^{52}$ and the Supreme Court of the People's Republic of China. ${ }^{53}$

Memoranda of guidance expressly provide that they have no binding legal effect and that they do not constitute any kind of legislation. They further provide that they only aim at promoting mutual understanding of the law of the participating court on enforcement of foreign judgments. And indeed, they each include separate parts where the most important rules and the requirements for enforcing foreign judgements under the law of each participating court are listed. Memoranda of guidance do not contain any assessment of the actual chances of enforcement of judgments rendered by the participating courts, and even less offer any guarantee of such enforcement. However, the mere existence of each of these memoranda suggests that the participating courts would enforce judgments rendered by each other. While these memoranda might not have any legal effect, ${ }^{54}$ they have a strong signalling effect, which explains why the relevant courts care to conclude them, and then to publicize them. It is unsurprising that the two courts which have concluded such instruments are international commercial courts with a strong interest in signalling the enforceability of their judgments abroad.

Of course, these memoranda typically insist that the goal is to improve reciprocal knowledge of the law of foreign judgments of the participating courts. They provide that they seek to "promote a mutual understanding of their laws and judicial processes". One can admit that the laws of some of the courts entering in these instruments might not have been restated in academic literature. In certain cases, it might be abstract, and a memorandum of guidance might be useful in making it more concrete. This is arguably the case of the law of foreign judgments of many middle-eastern states, which have a reciprocity requirement defined by reference to the law of the state of origin of the judgment. ${ }^{55}$ Bilateral memoranda of guidance could allow

\footnotetext{
${ }^{48}$ Memorandum of Understanding on Strengthening Judicial Exchange and Cooperation between Shanghai High People's Court and Dubai International Financial Centre Courts, dated October $26^{\text {th }}, 2016$.

${ }^{49}$ Memorandum of Guidance as to Enforcement of Money Judgments between the Supreme Court of the Republic of Singapore and Abu Dhabi Global Market Courts, dated March $8^{\text {th }}, 2017$.

${ }^{50}$ Exchange of Letters on cross-border enforcement of money judgments between Singapore International Commercial Court and Supreme Court of Victoria (Commercial Court), dated March 20 $0^{\text {th }}$ and $24^{\text {th }}, 2017$.

${ }^{51}$ Memorandum of Guidance as to Enforcement of Money Judgments between the Supreme Court of Singapore and the Supreme Court of Bermuda, dated September $6^{\text {th }}, 2017$.

${ }^{52}$ Memorandum of Guidance as to Enforcement of Money Judgments between the Supreme Court of the Republic of Singapore and Qatar International Court and Dispute Resolution Centre, dated October 17 2017.

${ }^{53}$ Memorandum of Guidance between the Supreme People's Court of The People's Republic of China and the Supreme Court of Singapore on Recognition and Enforcement of Money Judgments in Commercial Cases, dated August $31^{\text {st }}, 2018$.

${ }^{54}$ It is interesting to note, however, that a DIFC court held that, remarkably, a Memorandum of Understanding was useful to assess the content of its own law: "the English MOG (given that it was signed by the then Head of the English Commercial Court in its official capacity) serves as a starting point to guide the Court in the recognition and enforcement of a foreign judgment." See DNB Bank ASA v (1) Gulf Eyadah Corporation (2) Gulf Navigation Holdings Pjsc [2015] DIFC CA 007, at para 99 (available at https://www.difccourts.ae/2016/02/25/11421-2/ accessed on Feb. $\left.4^{\text {th }}, 2020\right)$.

55 Such provision is found in the laws of Egypt (art 296 of the Code of civil and commercial procedures), Kuwait (art 199 of Decree-Law No. 38/1980 promulgating the Law on civil and commercial procedures, as amended in 2007) and most importantly for the purpose of this article, Qatar (art 379 of Law No. 13 of 1990 on civil and commercial procedure, as amended in 2005) and the United Arab Emirates (art 235 of federal law no 11/1992 on civil procedure). In particular, art 235 of the UAE federal law, which applies in Dubai and Abu Dhabi, provides: " 1 - The execution of the decisions and orders delivered in a foreign country may be mandated in the state of the
} 
them to clarify how such a requirement would be applied with respect to judgments rendered by the other participating court, but there is no such need for the DIFC, which has special and straightforward requirements for enforcing foreign judgments. ${ }^{56}$ The situation in Singapore seems entirely different. There are a number of detailed accounts of the Singapore law of foreign judgments, available in the most commonly used language, English. ${ }^{57}$ It is unclear what the memoranda of guidance entered into by the Supreme Court of Singapore, which briefly describe the law of foreign judgments of Singapore, ${ }^{58}$ bring to the understanding of the laws and judicial process of that country. In truth, this is simply not the point. In a Multilateral Memorandum on Enforcement adopted under the aegis of the Standing International Forum of Commercial Courts, ${ }^{59}$ even the DIFC Courts recognised that that the first purpose of the bilateral memoranda of guidance that they signed was "to establish clearly that the DIFC Courts' judgments will be recognised and enforced in the countries with whom the DIFC Courts sign MOGs". ${ }^{60}$ In a speech delivered on September $14^{\text {th }}$, 2018, DIFC Courts Chief Justice Michael Hwang SC felt confident to go one step further: "through a series of memoranda with leading international jurisdictions the DIFC Courts have now established one of the world's strongest enforcement regimes." 61

The signalling function is at its peak when courts find it useful to enter into a memorandum which does not even contain a restatement of the law of each of the participating courts. This is the case of the memorandum of 'understanding' entered into by the DIFC Courts with the Shanghai High People's Court. ${ }^{62}$ The aim of the memorandum is merely to "recognize and strengthen bilateral cooperation supporting the internationalisation of judicial activities". ${ }^{63}$ It provides that the parties will "encourage candid, open and regular discussions", and that they will meet, though "on an irregular basis". From a marketing perspective, it seems that the prospect of entering into any kind of agreement with a court of the second trading power in the world is so attractive that the DIFC Courts thought it useful to publicize such a memorandum. In any case, the adoption of this instrument might have become counter-productive after the Supreme Court of Singapore entered into a more common memorandum of guidance with the Supreme Court of the PRC, ${ }^{64}$ which begs the question of why the DIFC Courts could not achieve the same result.

The next step for international courts could be to move from bilateral memoranda to a multilateral scheme. This is one of the goals of the Standing International Forum of Commercial

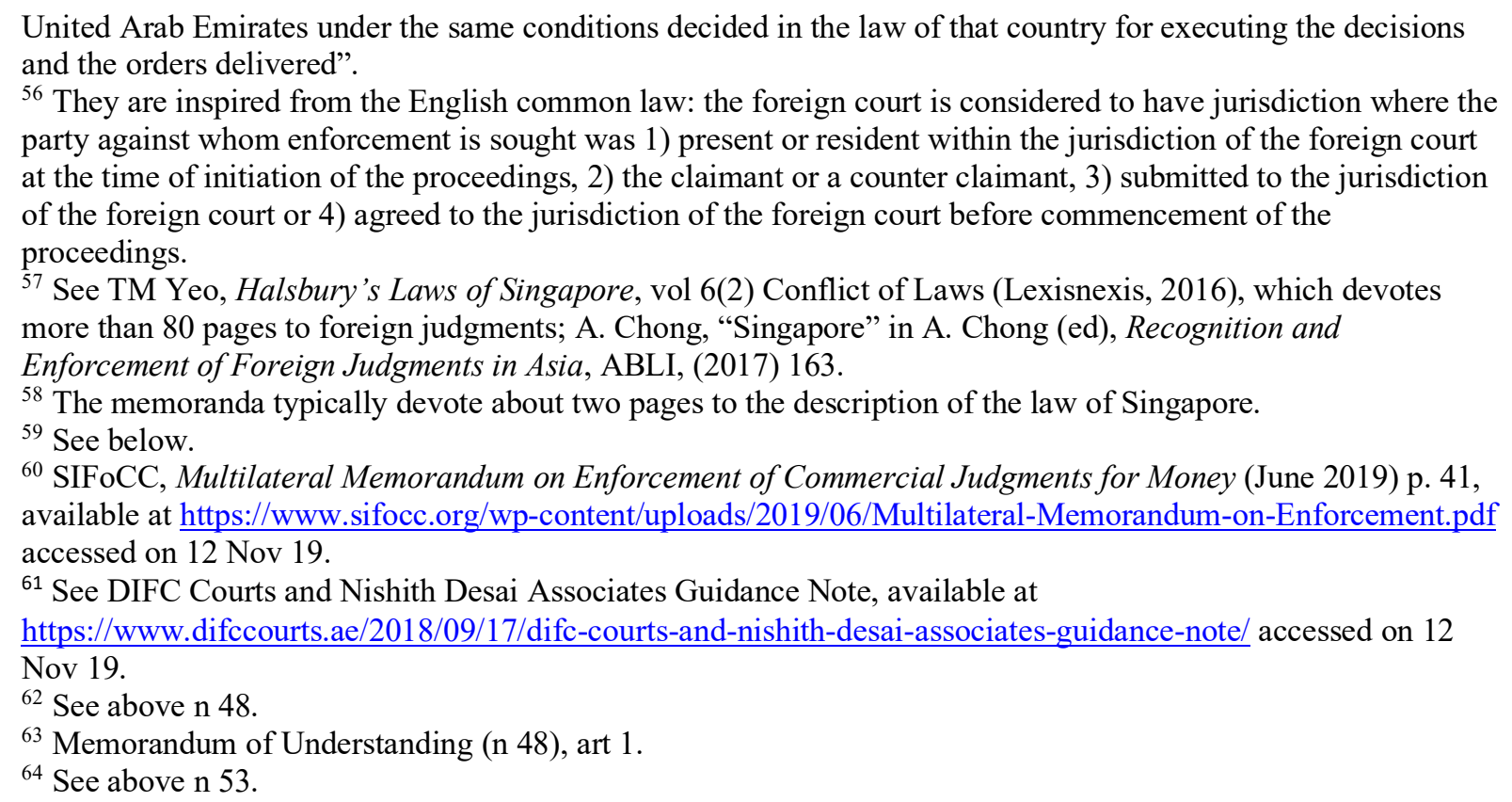


Courts (SIFoCC). ${ }^{65}$ SIFoCC was established in 2017 at the initiative of Lord Thomas, a former Lord Chief Justice of England and Wales. It aims at bringing together on a regular basis the judges from the world's commercial courts and facilitating collaboration. In June 2019, it completed what appeared to be its first goal, the adoption of a multilateral memorandum on enforcement of commercial judgments between members. ${ }^{66}$ The multilateral memorandum, which expressly provides that it is not binding, describes the law of enforcement of foreign judgments of 32 jurisdictions in a 107 page document. It is unclear, however, whether it can serve the same functions as bilateral memoranda. Clearly, it has the same informative value: it offers a brief description of the law of a number of states. Yet, a major difference is that the descriptions are abstract. They explain how "foreign judgments" in general may be enforced in a given jurisdiction. In contrast, bilateral memoranda are supposed to describe the law of enforcement of judgements rendered by the contracting court. Although the rules of each of the two courts are typically described with a similar degree of abstraction, the signalling function is much higher with a bilateral memorandum for the judgments of the other court. After adoption of the multilateral memorandum by SIFoCC, Lord Thomas stated: "This Memorandum is a landmark step. It shows to users the readiness of the world's commercial courts to enforce each other's judgments." ${ }^{67}$ Given the abstract nature of the memorandum, it is submitted that it precisely does not show any readiness to enforce foreign judgments coming from a particular jurisdiction. The signalling function is served by the statement of Lord Thomas rather than by the multilateral memorandum itself. In the second meeting of SIFoCC in September 2018, it was decided to "start work towards a second document that will identify shared principles for enforcement". ${ }^{68}$ If shared principles can be identified, and adhered to by participating courts, the usefulness of the project would increase significantly.

\section{2) Guiding Notes issued by foreign law firms}

Documents suggesting enforceability of judgments abroad could also be sought from private actors knowledgeable in the law of foreign judgments such as academics or law firms. Obviously, a major difference between courts and private actors is that the latter do not enjoy any authority to state the law. Although memoranda signed by courts expressly provide that they are non binding, courts always enjoy some residual authority in any activity they engage in. This is the foundation of the signalling power of such documents. If academics or law firms want to serve the same function, they must signal to the market the seriousness of their analysis in one way or another, or otherwise assume that their reputation is so high that it will suffice in this respect.

The DIFC Courts have sought restatements of the law of foreign judgments of foreign states from foreign law firms. Remarkably, they did so by replicating the model of Memoranda of Guidance and co-authoring with foreign law firms guides on the laws of foreign judgments of the two jurisdictions, i.e. the DIFC and the relevant foreign state. Thus, the guides contain a similar qualification providing that they are not binding on the courts of the relevant states, and do not constitute a treaty or legislation. ${ }^{69}$ This qualification which, for a document co-authored

\footnotetext{
${ }^{65} \mathrm{https}: / / \mathrm{www}$. sifocc.org/ accessed on 12 Nov 19.

${ }^{66}$ See above $\mathrm{n} 60$.

${ }^{67} \mathrm{https}$ ://www.sifocc.org/2019/06/24/multilateral-memorandum-on-enforcement/ accessed on 12 Nov 19.

${ }^{68}$ SIFoCC, Report of the Second Meeting, New-York 27-28 September 2018, available at https://www.sifocc.org/wp-content/uploads/2019/02/Report-of-the-Second-SIFoCC-Meeting-New-York2018.pdf accessed on 12 Nov 19

${ }^{69}$ See, e.g., Guide on Mutual Recognition and Enforcement of Civil and Commercial Judgments in DIFC Courts and Courts of India, dated 14 September 2018, para 2.1 (available at https://www.difccourts.ae/wpcontent/uploads/2018/09/Guide-between-DIFC-Courts-and-Nishith-Desai-Associates-on-Mutual-Recognitionand-Enforcement-of-Civil-and-Commercial-Judgments-in-DIFC-Courts-and-Courts-in-India.pdf accessed on 12 Nov 19).
} 
by a private actor, probably went without saying, suffices to show that such guides were entirely conceived as second best options, to be used only in those cases where the courts of the relevant countries would not agree to sign Memoranda of Guidance. In the multilateral memorandum of SIFoCC, the DIFC Courts reported:

Where the courts of certain countries have been reluctant to sign a formal MOG for diverse internal reasons (such as China, Japan and India), the DIFC Courts work with prominent law firms in those countries to develop Guidance Notes, replicating the formula on the information contained in the regular MOGs. One example is the Guide on Recognition and Enforcement of Civil and Commercial Judgments in the PRC Courts and the DIFC Courts. ${ }^{70}$

If the goal had really been to inform potential users about the content of the law of the relevant states, law firms might have appeared as perfectly apt to provide the service. But if the goal is to signal the enforceability of DIFC courts decisions abroad, it is unclear what such guides can bring. They were so obviously directly copied from bilateral memoranda signed by courts that they seem counterproductive. As the DIFC Courts were unable to design an appropriate document for involving law firms, these guides send two negative signals. The first is that only courts can be usefully involved to signal to signal the enforceability of DIFC Courts judgments abroad. The second is that the DIFC Courts were unable to sign a memorandum of understanding with the courts of the relevant country, which suggests that their judgment would not be enforced there.

There are, however, ways to involve usefully private actors, and there are ways for private actors to give signalling power to the documents they issue. As law and economics scholarship has long identified in other fields of the law, businesses can signal the quality of their products by committing to make good any defect which may arise. Sellers can offer warranties and, where such warranties are mandatory for a certain period, increase the duration of their warranties. ${ }^{71}$ Law firms can clarify that their assertions are statements on which third parties may rely, which may imply under the applicable law that the lawyers giving the opinion might be held liable if it appears that their assertions were inaccurate. ${ }^{72}$ This is the mechanism of third party legal opinions, which is commonly used in financial transactions. ${ }^{73}$

In the context of foreign judgments, international commercial courts willing to signal the enforceability of their judgments in certain jurisdictions could commission legal opinions from leading law firms admitted to practice law in those jurisdictions. Opinions asserting without significant qualifications the enforceability of the judgments rendered by a given international commercial court in a foreign jurisdiction would certainly send a strong signal to the market, so strong that it might surpass the signal sent by a Memorandum of Guidance signed with a local court.

In this respect, a model might be the policy of the International Swaps and Derivatives Association (ISDA) to signal the enforceability of its model contract, the ISDA Master Agreement. To that effect, ISDA has commissioned opinions on the enforceability of key provisions of its contract and related documentation in dozens of jurisdictions. ${ }^{74}$ Each opinion

\footnotetext{
${ }^{70}$ SIFoCC, Multilateral Memorandum on Enforcement (n 60), 42.

${ }^{71}$ See, e.g., A Schwartz \& R E Scott, Sales law and the contracting process (Foundation press, 2 ${ }^{\text {nd }}$ ed 1991$) 106$.

${ }^{72}$ For instance, under the tort of negligent misrepresentation in the United States: see e.g. Reich Family L.P. v. McDermott, Will \& Emery, No. 101921-03, 230 N.Y.L.J. 20, 20 col. I (N.Y. Sup. Ct. Oct. 29, 2003); Allen v. Steele, 252 P.3d 476, 482 (Colo. 2011).

${ }^{73}$ See generally H Lidstone, "the anatomy of a legal opinion" available at https://papers.ssrn.com/sol3/papers.cfm?abstract id=2261767 accessed on 12 Nov 19.

${ }^{74}$ ISDA states that such opinions cover 73 jurisdictions for certain provisions (netting) and 55 jurisdictions for other provisions (credit support documents), and that the opinions are generally updated on an annual basis. See https://www.isda.org/opinions-overview/, accessed on 12 Nov 19.
} 
is issued by a law firm based in one jurisdiction and advises on the enforceability of certain contractual provisions in that jurisdiction, subject to assumptions and qualifications. The opinions answer a questionnaire provided by ISDA. They conclude that they are written for the sole benefit of ISDA members and may not be relied upon by in other person, except with prior consent. Some add that the authors accept no responsibility to persons other than ISDA or ISDA members, which suggests that they do to ISDA members. In practical terms, this limitation is not significant, however, as the vast majority of actors in the industry are ISDA members, and only members could participate in the derivatives market.

\section{D) Rendering arbitral awards}

If the focus on enforceability of judgments aims primarily at showing that international commercial courts are as competitive as international commercial arbitration, then the most efficient solution might be to simply allow international courts to render arbitral awards which could benefit from the New York Convention.

At first sight, the proposition might appear as utterly contradictory. Courts deliver judgments, and arbitral tribunals only should deliver awards. Yet, the New York Convention does not define either the concept of arbitration or the concept of arbitral award, and the UNCITRAL Model Law on International Commercial Arbitration, which only explains that "arbitration means arbitration" ${ }^{75}$ has not contributed to any uniform definition. The concepts of arbitration and arbitral award are thus likely to vary from one legal system to another. Obviously, certain features seem to be necessary. One of them is that the parties should have consented to the jurisdiction of the adjudicator. Another is that the relevant adjudicatory process be alternative, i.e. different in some way from the ordinary judicial process. ${ }^{76}$ But, in most legal systems, there is no requirement concerning who the arbitrators should be. Notoriously, it is typically not required that they be lawyers or have any legal background but, conversely, it is not forbidden that they be lawyers, and it is typically not forbidden that they be judges. ${ }^{77}$ In truth, most of the features of the arbitral process do not seem to be necessary for characterizing the adjudication as being arbitration. Arbitration can be confidential, but, typically, need not be. Arbitrators charge fees, but so do certain courts. ${ }^{78}$

An interesting experiment, in this respect, was the Delaware arbitration programme. ${ }^{79}$ In 2009 , the state of Delaware granted its Court of Chancery "the power to arbitrate business disputes". ${ }^{80}$ The scheme, to which the parties had to consent, was to be "considered as confidential". ${ }^{81}$ Attendance at the proceeding was to be limited to "parties and their representatives," and all "materials and communications" produced during the arbitration were to be protected from disclosure in judicial or administrative proceedings. ${ }^{82}$ The parties were charged an initial filing

\footnotetext{
${ }^{75}$ Art 2(a) of the 1985 UNCITRAL Model Law provides: “arbitration” means any arbitration whether or not administered by a permanent arbitral institution'.

${ }^{76}$ See L A Mistelis \& D. di Pietro, "New York Convention, Article I [Scope of Application]", in Concise International Arbitration (LA Mistelis ed., Kluwer Law International 2d ed.2015) 3. A number of legal systems also require that arbitral awards finally settle the dispute. As there is no debate that decisions of international commercial courts do, I do not discuss this requirement further.

${ }^{77}$ Certain legal systems forbid that they be judges still in activity: see, e.g., in France, Ordinance no 5870 of 22 December 1958 on the Status of the Judiciary (as amended), Art 8.

${ }^{78}$ This is the case, for instance, in Austria for commercial cases, where courts charge a fee proportional to the value of the claim.

${ }^{79}$ See generally T Stipanowich, "In Quest of the Arbitration Trifecta, or Closed Door Litigation?: The Delaware Arbitration Program", (2013) 6 J. Bus. Entrepreneurship \& L. 349.

${ }^{80}$ H.B. 49, 145th Gen. Assemb. (Del. 2009). See 10 Del.Code Ann. tit. 10, § 349 (2009); Del. Ch. R. 96-98.

${ }^{81}$ Tit. 10, § 349(b); Del. Ch. R. 97(4).

${ }^{82}$ Del. Ch. R. 98(b).
} 
fee of US\$ 12,000 and US\$ 6,000 per day of service of the judge. One of the parties had to be a business entity organized under Delaware law and none of the parties could be a consumer and the amount-in-controversy had to be of at least one million dollars. The Delaware lawmaker did not seem concerned with the potential enforceability of the resulting judgments, but rather on possible appeals. It was thus decided that the court would render "orders", but that they could only be appealed in the Delaware court system under the limited grounds for review laid down in the U.S. Federal Arbitration Act 1925. In other words, they would borrow part of the regime of arbitral awards. The Delaware programme was ultimately found unconstitutional by U.S. courts on the ground that it violated the right of public access to the proceedings,${ }^{83}$ which could easily be fixed by making the proceedings public. ${ }^{84}$ But U.S. courts did not deny the programme the characterization of arbitration, ${ }^{85}$ although they noted that it clearly had special features. ${ }^{86}$

For lawmakers caring for the enforceability of the decisions of their international commercial courts, it might therefore be conceivable to grant them the power to deliver arbitral awards. A necessary condition would be that the parties agree to the jurisdiction of the court. As the New York Convention requires that the arbitration agreement be in writing and that the matter be capable of settlement by arbitration, it would be wise to meet these two conditions. It would then be for courts of other states to decide whether they would agree to consider the decisions of such courts as awards and enforce them under the New York Convention. It is likely that the debate would essentially focus on whether the process offered by the relevant international commercial courts would be alternative enough to qualify for the characterisation of arbitration. In this respect, important factors might be the autonomy of the relevant international commercial court in the local court system, the power afforded to the parties to design the adjudicatory process, the involvement of foreign judges. But one cannot see why the mere fact that the adjudicatory process would be handled by active judges in a courtroom would necessarily exclude arbitration.

The DIFC Courts have made a first step in that direction by proposing the conversion of their judgments into arbitral awards. ${ }^{87}$ The goal is not to allow DIFC Courts to deliver directly arbitral awards, ${ }^{88}$ but to do so only if their judgments face enforcement issues. In such cases, the judgement creditor may be entitled to initiate arbitration proceedings in order to obtain an arbitral award. The foundation of the power of the arbitral tribunal would lie in a special arbitration clause that the DIFC advises to include into the choice of court agreement granting jurisdiction to DIFC Courts. ${ }^{89}$ This conversion scheme does not seem to raise any issue of

\footnotetext{
${ }^{83}$ Delaware Coalition for Open Government v. Strine, 733 F.3d 510 (3d Cir. 2013).

${ }^{84}$ Instead, Delaware adopted in 2015 a new Delaware Rapid Arbitration Act offering traditional arbitration in Delaware under the supervision of the Court of Chancery.

85 "Nothing in today's decision should be construed to prevent sitting Judges of the Court of Chancery from engaging in arbitrations without those confidentiality provisions." Del. Coal. for Open Government, n 83, at 522. The dissent went even further: "In my view, such a set-up creates a perfect model for commercial arbitration" Id., at 524.

86 "Although Delaware's government-sponsored arbitrations share characteristics such as informality, flexibility, and limited review with private arbitrations, they differ fundamentally from other arbitrations because they are conducted before active judges in a courthouse, because they result in a binding order of the Chancery Court, and because they allow only a limited right of appeal". Del. Coal. for Open Government, n 83, at 518.

${ }^{87}$ D Demeter \& K M Smith, "The Implications of International Commercial Courts on Arbitration" (2016) J. Int. Arb. 441.

${ }^{88}$ The nature of DIFC judgments was questioned in Switzerland, however, but the Swiss federal tribunal ruled that they were to be characterized as foreign judgments and enforced as such: see Judgment no 5A_672/2015 of 2 September 2016 and Judgment no 5A_889/2016 of 30 March 2017.

89 “Any Judgment Payment Dispute (as defined in DIFC Courts Practice Direction No. 2 of 2015) that satisfies all of the Referral Criteria set out in the Practice Direction may be referred to arbitration by the judgment creditor, and such dispute shall be finally resolved by arbitration under the Arbitration Rules of the DIFC-LCIA Arbitration Centre, which Rules are deemed to be incorporated by reference into this clause." Suggested
} 
characterization. The award would be delivered by a traditional arbitral tribunal whose jurisdiction would lie in an arbitration clause. ${ }^{90}$ Furthermore, the narrow scope of the arbitration agreement appears to be perfectly tailored to the issue it wants to address, i.e. offering a solution in those cases where enforcement of judgments of DIFC courts is actually a problem. But the solution is very costly: it will be necessary to bring fresh proceedings on the judgment before an arbitral tribunal.

\section{E) Conclusion: remedies}

International commercial adjudication has become a business, and a number of states have established international commercial courts with the goal of attracting part of this business. In this context, it is logical that service providers market their services. But it would not be acceptable that they adopt strategies misleading potential customers. Under the law of sophisticated jurisdictions, markets are regulated, and rules of various kinds aim at sanctioning such practices, whether through public enforcement or by offering private remedies to customers.

The perception that enforceability of judgments abroad is an essential aspect of the attractiveness of their products has led some international courts to make statements or issue documents which either suggest or explicitly assert that their judgments would be enforceable in other jurisdictions. If these statements or documents were to be found to be misleading, this would raise the issue of the remedies available to aggrieved parties.

In most jurisdictions, deceptive advertising is a wrong which can either trigger public enforcement or tortious liability. Such regulatory schemes and torts, however, are primarily designed to regulate the activities of private actors. Courts are public bodies, which might fall outside of the scope of such rules in most jurisdictions. Abroad, courts will typically enjoy the sovereign immunities of the states which established them. Although it cannot be excluded that local rules governing the liability of public authorities might offer remedies, it seems unlikely that aggrieved parties could hold directly accountable international commercial courts.

Misrepresenting the enforceability of judgments abroad could also trigger challenges to the validity of choice of court agreements designating international commercial courts. A party could argue that he consented to the jurisdiction of a given court on the basis of the representation that judgments delivered by this court would be enforceable in jurisdictions where the other party would hold assets and, in particular, in the country of the judgment debtor's domicile. From a procedural perspective, the argument could be articulated by a plaintiff in the court of a jurisdiction where the defendant would own assets, but where the prospects of enforcement of a judgment delivered by the court designated in a choice of court agreement would appear to be low, or inexistent. The plaintiff would thus rely on a nonconsensual ground of jurisdiction and, should the existence of the choice of court agreement be raised, would argue that the agreement would be ineffective for lack of informed consent.

It would be for the law governing the substantive validity of the choice of court agreement to determine the grounds for challenging its effectiveness, and the form that the ineffectiveness

\footnotetext{
arbitration clause in the Amended DIFC Courts Practice Direction No. 2 of 27 May 2015, Referral of Judgment Payment Disputes to Arbitration.

${ }^{90}$ Demeter and Smith (n 87) seem to consider that the arbitration would be mere rubber stamping of the judgment of the DIFC Court, and that the alternativity requirement should be appreciated with respect to the judgment. There is no such suggestion in the model arbitration agreement (n 89). The basis for their argument might be that they cannot conceive a genuine enforcement dispute, but such disputes are common, and include disagreements on the method of payment (currency, set off, etc..), on the relevance of the existence of a contradictory decision or on whether the judgment could be time barred.
} 
would take. The grounds for challenging the effectiveness of the agreement could first include mistake, fraud, misrepresentation, or other vitiating factors known by the applicable law. While it is obviously not possible to make any general assessment on the prospects of success of such arguments, it can be underlined that a number of legal systems only afford remedies when the fraud or misrepresentation was made by the other party to the contract, and not when it was made by a third party. ${ }^{91}$ In the present context, the misrepresentation would have been made by the court or certain officials of the court, not by the other party. Other grounds of challenge could include unreasonableness, or pointlessness of an agreement which could not offer the most basic benefits it was meant to offer, i.e. finality of adjudication and enforceability. The form of the ineffectiveness could be voidness, nullity, or mere unenforceability.

The applicable law would be determined by reference to the choice of law rules of the forum, which would be likely to be a jurisdiction other than the one selected by the parties in the choice of court agreement. Under the 2005 Hague Convention ${ }^{92}$ and, in the European Union, under the Brussels Ibis Regulation, ${ }^{93}$ the applicable law should be the law of the chosen court in any case. For international commercial courts, this choice of law rule would have the distinct advantage of allowing to easily assess the prospects of success of any argument related to misrepresentation of enforceability of local judgments abroad. Yet, in practical terms, such argument would typically be based on the unavailability of any of these international regimes mandating the enforcement of foreign judgments and, out of their scope of application, any choice of law rule that they might provide would not apply either.

\footnotetext{
${ }^{91}$ This is the case, for instance, in England (Hasan v. Willson [1977] 1 Lloyd's Rep 431) or in France (Civil Code, art 1137).

922005 Hague Convention, art 6.

${ }^{93}$ Brussels Ibis Regulation, art 25.
} 